Original Research Article

\title{
Study of price variation among the different brands of anti-tubercular drugs available in India
}

\author{
Shreenivas P. R. ${ }^{1}$, S. Nagaraja Prasad ${ }^{2} *$
}

\author{
${ }^{1}$ Associate Professor, ${ }^{2}$ Assistant \\ Professor, Department of \\ Pharmacology, Shivamogga \\ Institute of Medical Sciences \\ (SIMS), Shimoga, Karnataka, \\ India
}

Received: 23 December 2016 Accepted: 18 January 2017

\section{*Correspondence to: \\ Dr. S. Nagaraja Prasad, \\ Email: \\ drnagarajprasad@gmail.com}

Copyright: (C) the author(s), publisher and licensee Medip Academy. This is an openaccess article distributed under the terms of the Creative Commons Attribution NonCommercial License, which permits unrestricted noncommercial use, distribution, and reproduction in any medium, provided the original work is properly cited.

\begin{abstract}
Background: India is one of the largest Tuberculosis (TB) burden countries in the world. Although Revised National Tuberculosis Control Programme provides free cost of therapy, sometimes patient get treated by private practioners. This can sometimes lead to irregular course of treatment due to decreased patient compliance. This in turn may lead to multi drug resistance among TB bacilli. One of the reasons for decreased patient compliance is cost of therapy. The present study was undertaken to evaluate the cost of therapy of various anti-TB drugs and their combinations available in India.

Methods: The maximum and minimum cost in rupees (INR) of all anti-TB drugs manufactured by various pharmaceutical companies was noted. The cost of 10 tablets/capsules or their fixed dose combinations (FDCs) was calculated. The cost ratio and percentage price variation were calculated for each brand and compared.

Results: Percentage variation in cost of oral anti-TB drugs marketed in India was highest in ethambutol 400mg (474.51), cycloserine 250mg (384.61), ethambutol 800mg (321.84) and rifampin 450mg (258.45). The lowest percentage cost variation was seen with pyrazinamide $225 \mathrm{mg}$ (10.04), ethambutol 1000mg (18.82) and rifampin 100mg (22.78).

Among the FDCs lowest percentage cost variation seen with rifampin $150 \mathrm{mg}$ +isoniazid $75 \mathrm{mg}+$ pyrazinamide $400 \mathrm{mg}(0.16)$ and highest percentage cost variation is seen with rifampin $450 \mathrm{mg}+$ isoniazid $300 \mathrm{mg}+$ pyrazinamide 750mg+ethambutol 800mg (232.73).

Conclusions: There is a significant variation in the cost of different brands of oral anti-TB drugs and their FDCs available in India. The National Pharmaceutical Pricing Authority (NPPA) should take more proactive steps for bringing down the prices of first line anti-TB drugs and the clinicians prescribing them should be aware of the price variation among the various brands of anti-TB drugs available in India.
\end{abstract}

Keywords: Anti-TB drugs, Compliance, Cost analysis, National Pharmaceutical Pricing Authority (NPPA)

\section{INTRODUCTION}

Tuberculosis (TB) is one of the top 10 causes of mortality worldwide. Six countries account for $60 \%$ of total cases in the world with India having maximum number of cases among the six leading countries. ${ }^{1}$ India accounts for 2.3 million of the 9.6 million Tuberculosis (TB) cases all over the world contributing to $1 / 4^{\text {th }}$ of the global incidence of TB. ${ }^{2,3} \mathrm{~TB}$ a communicable disease can affect any age, caste or class but mainly affects poorer strata of society. The economic burden of TB is said to be very high. TB in India costs Rs12000/- crore annually. The cost to patient for diagnosis and successful treatment averages US $\$ 100-1000 .^{4}$ TB treatment in India is undertaken by the Government of India through the Revised National TB Control Programme (RNTCP) as well as through the private sector health care providers. However not all the cases are identified properly and notified in proper time. The notification of TB cases is estimated to be only $58 \%$. Approximately $1 / 3^{\text {rd }}$ of cases are not diagnosed or they are diagnosed but were not treated or they may be diagnosed and treated but were not notified to the RNTCP center. ${ }^{2}$ In May 2012 India declared $\mathrm{TB}$ to be a notifiable disease. ${ }^{5}$ However 
according to one estimate by World Health organization nearly 10 lakh TB cases were not notified in India. ${ }^{2}$ Another study by Satyanarayana $\mathrm{S}$ et al indicates that nearly $46 \%$ of patients may not be reported to the RNTCP. ${ }^{6}$

Many people in India are unaware that all medicines needed for TB treatments are being provided free of cost by the government and therefore tend to seek treatment from the private sector. However there is a chance that the private sector can mismanage the TB treatment and thus lead to emergence of drug resistance.

The causes are many and may include incorrect use of diagnostic services, incorrect treatment protocols and a lack of supervision during anti-TB therapy. All these factors may lead to emergence of drug resistance forms of TB like MDR-TB, XDR-TB.

Thus the poor patients with inadequate financial resources who may not complete treatment with the private practitioner may further complicate the existing situation.

Therefore, the present study was undertaken to evaluate the cost variation of anti-TB drugs in India.

\section{METHODS}

Prices of various anti-TB drugs were obtained from the latest issue of CIMS July-Oct 2016 and Indian Drug Review Vol XXII Issue 32016.

The maximum and minimum cost of anti-TB drugs in Rupees (INR) manufactured by different pharmaceutical companies in same dose and formulation were noted. The cost of 10 tablets/capsules was calculated.

The cost ratio, i.e. ratio of costliest to cheapest brand of the same generic anti-TB drug is calculated. This gives an estimate of how many times the costliest brand costs more than the cheapest one in each generic group. Percentage cost variation is calculated as follows:

\section{$\%$ Cost variation $=($ Maximum cost-minimum cost $)$ Minimum cost X 100}

Fixed dose combination of anti-TB drugs were also included in the present study.

\section{RESULTS}

The highest cost ratio was seen with ethambutol $400 \mathrm{mg}$ (5.75), cycloserine 250mg (4.85), ethambutol $800 \mathrm{mg}$ (4.22) and rifampin 450mg (3.58).

Table 1: Cost variation of various anti-TB drugs available in India.

\begin{tabular}{|c|c|c|c|c|c|c|}
\hline $\begin{array}{l}\text { SI } \\
\text { no }\end{array}$ & Drug & Dose (mg) & $\begin{array}{l}\text { Maximum cost } \\
\text { (inr) }\end{array}$ & $\begin{array}{l}\text { Minimum } \\
\text { cost (inr) }\end{array}$ & Cost ratio & $\begin{array}{l}\text { \% price variation of } \\
10 \text { tablets/capsule }\end{array}$ \\
\hline \multirow{2}{*}{1} & \multirow{2}{*}{ Isoniazid(tab) } & $100 \mathrm{mg}$ & --- & 8.40 & 1 & 0 \\
\hline & & $300 \mathrm{mg}$ & 86 & 27.60 & 3.12 & 211.59 \\
\hline \multirow{8}{*}{2} & \multirow{5}{*}{$\begin{array}{l}\text { Rifampin } \\
\text { capsule }\end{array}$} & $100 \mathrm{mg}$ & --- & 15.61 & 1 & 0 \\
\hline & & $150 \mathrm{mg}$ & 21.78 & 17.74 & 1.23 & 22.78 \\
\hline & & $300 \mathrm{mg}$ & 47.03 & 30.13 & 1.56 & 56.09 \\
\hline & & $450 \mathrm{mg}$ & 68.93 & 19.23 & 3.58 & 258.45 \\
\hline & & $600 \mathrm{mg}$ & 92.5 & 54.27 & 1.70 & 70.44 \\
\hline & \multirow{3}{*}{ Tablet } & $300 \mathrm{mg}$ & --- & 47.03 & 1 & 0 \\
\hline & & $450 \mathrm{mg}$ & 68.93 & 47.65 & 1.45 & 44.66 \\
\hline & & $600 \mathrm{mg}$ & --- & 92.50 & 1 & 0 \\
\hline \multirow{7}{*}{3} & \multirow{7}{*}{ Pyrazinamide tablet } & $250 \mathrm{mg}$ & 29.60 & 26.90 & 1.10 & 10.04 \\
\hline & & $300 \mathrm{mg}$ & --- & 32.56 & 1 & 0 \\
\hline & & $500 \mathrm{mg}$ & 52.54 & 35.30 & 1.49 & 48.84 \\
\hline & & $750 \mathrm{mg}$ & 86.87 & 26.76 & 3.24 & 224.63 \\
\hline & & $1000 \mathrm{mg}$ & 105.50 & 35.42 & 2.98 & 197.85 \\
\hline & & $1200 \mathrm{mg}$ & --- & 115 & 1 & 0 \\
\hline & & $1500 \mathrm{mg}$ & --- & 113.40 & 1 & 0 \\
\hline \multirow{5}{*}{4} & \multirow{5}{*}{ Ethambutol tablet } & $200 \mathrm{mg}$ & 11.11 & 3.92 & 2.83 & 183.42 \\
\hline & & $400 \mathrm{mg}$ & 41.25 & 7.18 & 5.75 & 474.51 \\
\hline & & $600 \mathrm{mg}$ & 39.84 & 20.25 & 1.97 & 96.74 \\
\hline & & $800 \mathrm{mg}$ & 57.75 & 13.69 & 4.22 & 321.84 \\
\hline & & $1000 \mathrm{mg}$ & 66.16 & 55.68 & 1.19 & 18.82 \\
\hline 5 & Ethionamide tablet & $250 \mathrm{mg}$ & 138.50 & 107 & 1.29 & 29.44 \\
\hline 6 & Prothionamide tablet & $250 \mathrm{mg}$ & --- & 149 & 1 & 0 \\
\hline \multirow{2}{*}{7} & Cycloserine capsule & $250 \mathrm{mg}$ & 485 & 100.08 & 4.85 & 384.61 \\
\hline & Tablet & $250 \mathrm{mg}$ & 416.25 & 416.25 & 1 & 0 \\
\hline
\end{tabular}


Lowest cost ratio was seen with pyrazinamide $250 \mathrm{mg}$ (1.10), ethambutol $1000 \mathrm{mg}$ (1.19) and rifampin $150 \mathrm{mg}$ (1.233).

The percentage cost variation is highest with ethambutol 400mg (474.51), cycloserine 250mg (384.61), ethambutol 800mg (321.84) and rifampin 450mg (258.45).

The lowest percentage cost variation was seen with pyrazinamide $250 \mathrm{mg}$ (10.04), ethambutol 1000mg (18.82) and rifampin 100mg (22.78).

Among the Fixed Dose Combinations the lowest cost ratio was seen with isoniazid $75 \mathrm{mg}+$ rifampin $150 \mathrm{mg}$ tablet(1.04) followed by rifampin $225 \mathrm{mg}+$ isoniazid $150 \mathrm{mg}+$ pyrazinamide $750 \mathrm{mg}$ tablet (1.05) and the highest cost ratio is seen with rifampin $450 \mathrm{mg}+$ isoniazid $300 \mathrm{mg}+$ pyrazinamide $750 \mathrm{mg}+$ ethambutol $800 \mathrm{mg}$ (3.33) followed by isoniazid 300mg+ ethambutol 800mg (2.28). The highest percentage cost variation is seen with: rifampin 450mg+ isoniazid 300mg+ pyrazinamide $750 \mathrm{mg}+$ ethambutol $800 \mathrm{mg}$ (232.73) followed by isoniazid $300 \mathrm{mg}$ + ethambutol $800 \mathrm{mg}$ (127.59) while the lowest percentage cost variation was seen with rifampin $150 \mathrm{mg}+$ isoniazid $75 \mathrm{mg}+$ pyrazinamide $1100 \mathrm{mg}(0.16)$ followed by rifampin $120 \mathrm{mg}+$ isoniazid $80 \mathrm{mg}+$ pyrazinamide $250 \mathrm{mg}(0.64)$.

Table 2: Cost variation of various anti-TB fixed dose combinations in India.

\begin{tabular}{|c|c|c|c|c|c|}
\hline $\begin{array}{l}\text { Sl. } \\
\text { No. }\end{array}$ & Fixed dose combination & $\begin{array}{l}\text { Maximum } \\
\text { cost }\end{array}$ & $\begin{array}{l}\text { Minimum } \\
\text { cost }\end{array}$ & $\begin{array}{l}\text { Cost } \\
\text { ratio }\end{array}$ & $\begin{array}{l}\text { \% Price variation of } \\
10 \text { tablets/ Capsules }\end{array}$ \\
\hline 1 & Isoniazid 300mg+ Ethambutol $800 \mathrm{mg}$ & 69.87 & 30.7 & 2.28 & 127.59 \\
\hline \multirow{10}{*}{2} & Isoniazid+Rifampin & & & & \\
\hline & $30 \mathrm{mg}+60 \mathrm{mg}$ & --- & 9.62 & 1 & 0 \\
\hline & $50 \mathrm{mg}+100 \mathrm{mg}$ & 15.43 & 12.97 & 1.19 & 18.97 \\
\hline & $75 \mathrm{mg}+150 \mathrm{mg}$ & 19.20 & 18.53 & 1.04 & 3.62 \\
\hline & $100 \mathrm{mg}+100 \mathrm{mg}$ & 15.31 & 12.12 & 1.26 & 26.32 \\
\hline & $100 \mathrm{mg}+150 \mathrm{mg}$ & --- & 19.17 & 1 & 0 \\
\hline & $150 \mathrm{mg}+300 \mathrm{mg}$ & 49.50 & 34.18 & 1.45 & 44.82 \\
\hline & $225 \mathrm{mg}+450 \mathrm{mg}$ & 69.50 & 51.23 & 1.36 & 35.66 \\
\hline & $300 \mathrm{mg}+450 \mathrm{mg}$ & 67.74 & 37 & 1.83 & 83.08 \\
\hline & $300 \mathrm{mg}+600 \mathrm{mg}$ & 77.17 & 56.8 & 1.36 & 35.86 \\
\hline \multirow{8}{*}{3} & Rifampin+Isoniazid+Ethambutol & & & & \\
\hline & $150 \mathrm{mg}+75 \mathrm{mg}+275 \mathrm{mg}$ & 39.90 & 28.73 & 1.39 & 38.88 \\
\hline & $150 \mathrm{mg}+100 \mathrm{mg}+275 \mathrm{mg}$ & --- & 34.75 & 1 & 0 \\
\hline & $150 m g+275 m g+275 m g$ & --- & 30.78 & 1 & 0 \\
\hline & $150 \mathrm{mg}+300 \mathrm{mg}+550 \mathrm{mg}$ & 74.50 & 57.64 & 1.29 & 29.25 \\
\hline & $450 \mathrm{mg}+225 \mathrm{mg}+550 \mathrm{mg}$ & --- & 86.43 & 1 & 0 \\
\hline & $450 \mathrm{mg}+225 \mathrm{mg}+825 \mathrm{mg}$ & --- & 102 & 1 & 0 \\
\hline & $450 \mathrm{mg}+300 \mathrm{mg}+800 \mathrm{mg}$ & 95.75 & 43.35 & 2.21 & 120.88 \\
\hline \multirow{10}{*}{4} & Rifampin+Isoniazid+Pyrazinamide & & & & \\
\hline & 60mg+30mg+150mg & --- & 13.72 & 1 & 0 \\
\hline & $100 \mathrm{mg}+50 \mathrm{mg}+300 \mathrm{mg}$ & -- & 24.60 & 1 & 0 \\
\hline & $120 \mathrm{mg}+80 \mathrm{mg}+250 \mathrm{mg}$ & 30.09 & 29.90 & 1 & 0.64 \\
\hline & $150 \mathrm{mg}+100 \mathrm{mg}+375 \mathrm{mg}$ & --- & 42.25 & 1 & 0 \\
\hline & $150 \mathrm{mg}+75 \mathrm{mg}+400 \mathrm{mg}$ & 30.58 & 30.53 & 1 & 0.16 \\
\hline & $150 \mathrm{mg}+100 \mathrm{mg}+500 \mathrm{mg}$ & 53.60 & 34.17 & 1.57 & 56.86 \\
\hline & $225 \mathrm{mg}+150 \mathrm{mg}+750 \mathrm{mg}$ & 51.76 & 49.40 & 1.05 & 4.78 \\
\hline & $450 \mathrm{mg}+300 \mathrm{mg}+750 \mathrm{mg}$ & --- & 161.10 & 1 & 0 \\
\hline & $450 \mathrm{mg}+300 \mathrm{mg}+1500 \mathrm{mg}$ & 162.70 & 149.50 & 1.09 & 8.83 \\
\hline \multirow{8}{*}{5} & Rifampin+Isoniazid+Pyrazinamide+Ett & & & & \\
\hline & $150 m g+75 m g+400 m g+275 m g$ & 47 & 29.23 & 1.61 & 61.07 \\
\hline & $150 \mathrm{mg}+100 \mathrm{mg}+500 \mathrm{mg}+275 \mathrm{mg}$ & 51 & 48.07 & 1.06 & 6.10 \\
\hline & $225 \mathrm{mg}+150 \mathrm{mg}+750 \mathrm{mg}+400 \mathrm{mg}$ & 71 & 62.23 & 1.14 & 14.09 \\
\hline & $450 \mathrm{mg}+300 \mathrm{mg}+750 \mathrm{mg}+800 \mathrm{mg}$ & 147.90 & 44.45 & 3.33 & 232.73 \\
\hline & $450 \mathrm{mg}+300 \mathrm{mg}+1500 \mathrm{mg}+1800 \mathrm{mg}$ & 185.40 & 107.80 & 1.72 & 71.99 \\
\hline & $600 \mathrm{mg}+300 \mathrm{mg}+800 \mathrm{mg}+1100 \mathrm{mg}$ & --- & 164.80 & 1 & 0 \\
\hline & $450 \mathrm{mg}+225 \mathrm{mg}+1200 \mathrm{mg}+825 \mathrm{mg}$ & --- & 37.26 & 1 & 0 \\
\hline
\end{tabular}




\section{DISCUSSION}

TB is one of the India's biggest health problems. According to WHO India has the world's largest TB epidemic. It affects about 300 million Indians and is responsible of $21 \%$ of global incidence burden in India. ${ }^{7}$ This causes a large economic burden with an estimated economic loss of US \$43 billion and 100 million lost annually to the disease which a developing country like India cannot afford easily. ${ }^{8}$ Although the anti-TB drugs can be freely procured at Government run hospital, many patients are not able to use this benefit because of various reasons and spend huge amounts for treatment in private hospitals. ${ }^{9}$ Some reasons may be that nearly $1 / 3^{\text {rd }}$ of cases may not be diagnosed or they may be diagnosed but not treated or they may be diagnosed and undergo treatment but may not be reported to the RNTCP programme. ${ }^{2}$ One of the reasons for the low case notification is the largely unregulated and unmonitored private sector which accounts for nearly half of total TB cases treated in India. ${ }^{10}$ Other reasons include poor knowledge about TB, poor knowledge of services available through the National Programmes, the assumed convenience of services in the private sector, a desire for confidentiality and a desire for personalized care.

In order to improve these factors the private practitioners should ensure that all the patients complete full treatment course of treatment with anti-TB drugs. One of the ways to ensure this is to see that the cost of anti-TB medications does not have a very high impact on patient's expenses. Different studies have concluded that if a comparative manual of drug prices is available to the physicians it will change the prescribing practices towards lower priced medications and it will reduce the cost of therapy tremendously. ${ }^{11}$ Since the superiority of costliest brand of drug over the cheapest brand has never been scientifically established, a patient welfare centred physician should always chose the cheapest generic version of medication to improve patient compliance. ${ }^{12}$ Also the National Pharmaceutical Pricing Authority (NPPA) should take more proactive steps to ensure that the prices of essential first line anti-TB drugs and their combinations are brought under control so that all patients irrespective of the underlying cause should be able to afford these medicines and get treated completely. Also the private practitioners should be made aware of these existing price differences in the cost of various brands of anti-TB drugs and their combinations and should be educated to choose the most affordable brand available locally in the country.
Funding: No funding sources

Conflict of interest: None declared

Ethical approval: Not required

\section{REFERENCES}

1. WHO/Tuberculosis. Available at: http://who.int/mediacentre/factsheets/fs104/en.

2. TB statistics for India. TB facts.org. Available at: http:// www.tbfacts.org/tb-statistics-India.html.

3. Lal S, Adarsh, Pankaj. Textbook of Community Medicine. Preventive and Social Medicine, $4^{\text {th }}$ ed. CBS publishers and Distributors Pvt Ltd, New Delhi; 2014:443,548.

4. WHO. Global Tuberculosis Report 2016.Geneva, Switzerland: WHO, 2016. Available at http://www.who.int/tb/publications/Global Tuberculosis Report 2016.

5. Sinha K. Finally tuberculosis declared a notifiable disease. The Times of India May 9, 2012. Available at http://articles.timesofindia.indiatimes.com/201205-09/india/.

6. Satyanarayana S, Nair SA, Chadha SS, Sivashankar R, Sharma G, Yadav S et al. From where are TB patients accessing treatment in India? Results from a cross-sectional community based survey of 30 districts. 2011;6(9):e24160.

7. WHO Report 2010: Global Tuberculosis control. Epidemiology, strategy and Financing. Geneva: WHO; 2010.

8. Udwadia ZF. MDR, XDR, TDR tuberculosis: omnious progression. Thorax 2012;67(4):286-8. Available from: http://thorax.bmj.com/content/67/4/286 pdf.

9. Chorghade B. To fight MDR-TB, act on time. Available http://dnasyndication.com/dna/Mumbai/.

10. Bhargava A, Pinto L, Pai M. Mismanagement of tuberculosis in India: causes, consequences and the way forward. Hypothesis. 2011;9:e7.

11. Frazier LM, Brown JT, Divine GW, Fleming GR, Philips NM, Siegel WC. Can physician education lower the cost of prescription drugs? A prospective, controlled trial. Ann Intern Med. 1991;115(2):11621.

12. Lal A, Sharma M L. A calm look at the cost of drugs in psychiatric practice. Indian $\mathrm{J}$ Psychiatry. 1992;34(1):18-20.

Cite this article as: Shreenivas PR, Prasad SN. Study of price variation among the different brands of anti-tubercular drugs available in India. Int J Basic Clin Pharmacol 2017;6:660-3. 